\title{
Papers
}

\section{Attitudes towards American brands and Brand America}

Received (in revised form): 11th July, 2007

\section{Jami A. Fullerton}

obtained her PhD from University of North Texas and is an associate professor at Oklahoma State University. She is the author of Advertising's War on Terrorism with Alice Kendrick. Her research interests include cross-cultural communication and media globalisation.

\section{Alice Kendrick}

obtained her PhD from University of Tennessee and is Professor of Advertising in the Temerlin Advertising Institute, Southern Methodist University in Dallas, Texas, USA. Her research interests include mass media and public diplomacy, advertising employment issues and advertising education.

\section{Kara Chan}

obtained her PhD from City University of Hong Kong and teaches advertising and public relations at the Department of Communication Studies of the Hong Kong Baptist University. Her research areas include cross-cultural advertising, and advertising and children.

\section{Matthew Hamilton}

obtained his EdD from Oklahoma State University and is the Chair of the Mass Communications Department at Oklahoma City University. He teaches advertising and public relations courses on campus as well as in Singapore with the Management Development Institute of Singapore. His research areas include propaganda, cross-cultural advertising and agency management.

\section{Gayle Kerr}

obtained her PhD from Queensland University of Technology, Australia and teaches advertising and integrated marketing communication at the School of Advertising, Marketing and Public Relations at the Queensland University of Technology in Brisbane, Australia. Her research areas include integrated marketing communication, advertising regulation and ethics and advertising management.

Correspondence: Jami A. Fullerton, Oklahoma State University, 700 N. Greenwood Ave., Tulsa, Oklahoma, OK 74106, USA. Tel: +19185948579

Fax: +19185948281 e-mail: jami.fullerton@okstate.edu
Abstract A study of 556 students at colleges and universities in Australia, Hong Kong and Singapore explored the relationship between attitude towards the United States and brand attitudes and preferences. Singaporean student attitudes towards both the US Government and US people were higher than were those of the Australian and Hong Kong students. Coke, Nike and McDonald's were among both the most-liked and disliked US brands among the international students, a finding suggesting that brands may possess both a 'lovemark' status, as described in the literature, and its opposite - 'loathemark' status - within the same demographic group. US brand preference scores did not offer support for the belief that international consumers 'vote with their pocketbooks' by refusing to purchase US brands if they have a negative attitude towards the United States. Among Hong Kong and Singaporean students, favourable attitudes towards the purchase of US brands was found to be positively related to favourability towards the US Government. Place Branding and Public Diplomacy (2007) 3, 205-212. doi:10.1057/palgrave.pb.6000063

Keywords: Attitude towards America, US brands, Asia-Pacific countries, anti-Americanism 


\section{INTRODUCTION}

International polls since 9/11 reveal continuing high-levels of anti-Americanism among citizens of other countries (Pew, 2006), including US allies such as Japan and Spain. Anti-Americanism not only affects the US Government's foreign policy and international interests but also presents specific concerns for American business. Some industry leaders fear that foreign citizens' increasingly hostile attitudes towards America may hurt US businesses' bottom lines (Reinhard, 2003), while others assert that American brands have not been affected by the recent declines in US favourability (Guyon, 2003; Romero, 2004).

This paper explores the relationship between American brands and 'Brand America' through the comparative analysis of survey findings from college students in three Pacific Rim countries - Australia, Hong Kong and Singapore. The paper attempts to discover how anti-

Americanism may be impacting US global marketers by investigating international young people's US brand attitudes and preferences.

\section{BACKGROUND}

\section{Attitude towards America}

International public opinion polls conducted since 9/11, most notably the Pew Center for the People and the Press Global Attitudes Project, have revealed an increase in antiAmericanism. The Global Attitudes Project measures the values and attitudes of people in countries worldwide (Pew, 2006). The most recent Pew study reports 'US global image has slipped again' (Pew, 2006).

The first project was released in December 2002, with updates in March 2003 (before the Iraq war), May 2003 (after the Iraq war was declared over by the United States), March 2004, May 2005 and June 2006. The Pew Global Attitudes Project does not include Australia, Hong Kong or Singapore in its worldwide survey, but attitudes from other Asian countries were measured. For example, in 2002, favourability ratings in Indonesia were 61 per cent and then fell to 15 per cent in May 2003. After the tsunami and the outpouring of US aid, favourability ratings in Indonesia increased to 38 per cent, but slipped to 30 per cent in June 2006 (Pew, 2006). Japan, a traditional US ally, holds a favourability rating of only 63 per cent, down from 72 per cent in 2002. In a separate study, Pew reported that more than 71 per cent of young South Koreans (18-29year-old age group) hold an unfavourable view of the United States (Robertson, 2006).

A closer examination of the polls reveals that the negative feelings towards America among people in other countries are often tied to US policy, not to the US people or American values (Telhami, 2003). A Zogby poll, for example, revealed that when asked about 'American freedom and democracy', 'American education', 'American products' and the 'American people', Arabs were overwhelmingly positive. When asked, however, about the American policy towards Palestinians, Iraq or the Arab world in general, they were harshly negative (Zogby, 2003). Polls in Europe show that people dislike American foreign policy, particularly with regard to the war in Iraq, but that they separate those feelings from American products, people and business, which they like (Guyon, 2003).

\section{Anti-Americanism and US brands}

Overwhelming negative attitudes towards America among international audiences have caused concern for American business executives who fear that anti-Americanism will affect their sales and profits (Guyon, 2003). Recognising that they have little direct influence on international policies, some business leaders have come together to restore America's image on their own. Most notably in this effort is Business for Diplomatic Action (BDA), headed by Keith Reinhard, former chairman of advertising giant DDB Worldwide. BDA aims to 'improve the standing of America in the world' (Business for Diplomatic Action, 2006) through actions, not ads. Reinhard believes that much of the hostility towards America can be traced to a type of cultural imperialism that results from 'US global business expansion’ (Reinhard, 2003). 
Similarly, Tim Love, vice-chairmaninternational of Saatchi \& Saatchi, another international ad agency, called for global marketers to be sensitive to the cultures of countries in which they conduct business and help improve the lives of the people who live there. Love believes that in some cases people are more 'in touch with icons like Coca-Cola and McDonald's than with their own government' (Love, 2003). Certain brands, according to Saatchi CEO Kevin Roberts, are so personally revered by consumers that they attain the enviable status of 'Lovemarks' both in the US and abroad (Roberts, 2004).

As anti-Americanism grows, some global marketers have redesigned their logos and brand names to shed their 'all-American' image (Elliott, 2003). Recent international advertising studies have shown that connecting products to America, once a brand asset, may now be a negative strategy (Avraham and First, 2003; Elliott, 2003).

Other studies have denied that antiAmericanism is hurting US brands, citing economic effects rather than political effects as a source of declining sales (Romero, 2004). Business Week's ranking of the top 100 most valuable brands worldwide showed that American brands still hold 62 of the top spots. Among the strongest were Coke, Microsoft and IBM. The study quoted a South Korean engineer as saying "calling for political independence from the US is one thing and liking American brands is another. Of course I like IBM, Dell, Microsoft, Starbucks and Coke' (Kermouch et al., 2003). A recent empirical study conducted by researchers at Princeton and Cornell showed no relationship between rising anti-Americanism and sales of top US brands (The Economist, 2005). The researchers concluded, 'reports of consumer anti-Americanism damaging sales of US-based firms in Europe are highly exaggerated' (Gross, 2006).

\section{Australia}

Australia is the sixth largest country in the world, equal in size to the 48 mainland states of the United States and 50 per cent larger than Europe. Populated by only 20.6 million
Australians, it has the lowest population density in the world. This affects the lifestyle and values of its inhabitants and the structure and the function of its government and business.

Australia has a stable, democratic government, which guides a strong economy. The Gross Domestic Product was up 2.3 per cent in 2005 to $\$ \mathrm{~A} 859,192 \mathrm{~m}$. Retail sales also grew by 4.3 per cent, encouraged by a rise in the average annual wage of 4.8 per cent to $\$ \mathrm{~A}$ 1,032 per week (Australian Bureau of Statistics, 2006). Advertising is an important business in Australia with $\$ \mathrm{~A} 4.5 \mathrm{bn}$ invested in mainstream media in the six months to June 2005 (Australian Federation of Advertising, 2006).

Australia is a popular tourist destination, attracting 5.5 million visitors in the year ended 31st July, 2006. Of these, 451,100 came from the United States, a 1 per cent increase on the previous year (Australian Bureau of Statistics, 2006).

\section{Hong Kong}

Hong Kong, located on the coast of southern China, was a former British colony that was returned as a Special Administrative Region (SAR) of China in 1997. Hong Kong is one of the most densely populated territories in the world with 7 million people residing in about $1,100 \mathrm{~km}^{2}$ of land. The society is dominated by Chinese (94.9 per cent), Filipino (2.1 per cent) and Indonesian ( 0.8 per cent). Chinese and English are the official languages, with English used mainly in the government and by the legal, professional and business sectors. Cantonese (often with English words embedded) is the major medium of daily communication.

Hong Kong is the world's 11th largest trading economy and Asia's second largest stock market. It is one of the world's top exporters of clothing, watches, toys, electronic products and light industrial goods. Hong Kong is a servicebased economy, with the services sector contributing 87 per cent of the territory's GDP in 2002. The Hong Kong SAR Government is proud of its laissez faire policy, press freedom, established legal system and the entrepreneurial flair of its citizens. 
Hong Kong people generally have favourable attitudes towards people from Western countries, including Americans and Europeans. American popular culture prevails in Hong Kong through movies and drama series occurring on the English channels of local television. Expatriates are perceived as knowledgeable, open-minded, modern and friendly. Due to the relatively small expatriate population in Hong Kong, most of the Hong Kong people have not had personal contacts with Americans.

\section{Singapore}

Singapore is a tiny island nation located in Southeast Asia between Malaysia and Indonesia - two of the world's largest Muslim countries. Singapore is about three times the size of Washington DC with a population of 4.4 million. The multi-racial society is divided into three main segments: Chinese (76.7 per cent), Malay (14 per cent) and Indian (7.9 per cent). English is recognised as the common language for all Singaporeans. Because Singapore is located in the diverse region of Southeast Asia, the government encourages social harmony and racial cohesion.

Singapore is considered a thriving economic success story in a volatile part of the world. It is, however, also seen as an authoritarian state that limits free speech and political choice. Though the Singaporean Government discourages Western values, the nation of Singapore has enjoyed good relations with the United States over the years and has been a strategic military ally.

According to Kluver and Fu's (2004) Cultural Globalisation Index, Singapore is the most globalised country in the world, based on its consumption of mass communication products from overseas. Therefore, Singaporeans are heavily exposed to American popular culture, especially to Hollywood movies, music and television.

\section{RESEARCH QUESTIONS}

To better understand the relationship between anti-Americanism and US brand preference, a survey of college students in Australia, Hong
Kong and Singapore was conducted. Specifically the following questions were investigated:

1. What are the prevailing attitudes towards America among students in Australia, Hong Kong and Singapore?

2. Which American brands do students in Australia, Hong Kong and Singapore like most? Least?

3. What is the degree of preference for US brands among students in Australia, Hong Kong and Singapore?

4. Is there a relationship between US brand preference and attitude towards America?

\section{METHODOLOGY}

Pencil-paper surveys were administered in English by local professors in a classroom setting in Australia, Hong Kong and Singapore. One hundred and sixty-one undergraduate students at Queensland University of Technology in Australia, 67 students enrolled in senior-level (bachelors) and masters programmes at Hong Kong Baptist University and 328 advanced diploma and bachelors students in the Management Development Institute of Singapore completed the surveys in July 2005, March 2005 and March 2004, respectively.

The same instrument was used in all countries and consisted of a 13-page questionnaire that first measured attitude towards the US Government and the US people on a 4-point scale from very favourable (4) to very unfavourable (1). Degree of preference for US brands was then measured on a 5 -point scale with 5 indicating strong preference for US brands and 1 indicating refusal to purchase US brands.

Open-ended items had students name US brands that they liked and disliked and words that described America and Americans. Several demographic questions, including age, gender, native language, ethnicity, religious preference and country of citizenship also were included. Students were asked if they knew anyone in the United States, whether they had visited the United States and if they would like to visit some day. 


\section{FINDINGS}

\section{Respondent Profile}

\section{Australia}

Seventy-two per cent of the students who participated were female and 28 per cent were male. Average age of the participants was 20.4 years, with a range of 17-37. Seventy-eight per cent said English was their native language. The rest indicated several native languages, including Chinese ( 6 per cent) and Cantonese ( 4 per cent). Ninety-four per cent said they spoke English fluently.

Most participants were from Australia (92.0 per cent), followed by China (6.0 per cent). Asked if they knew anyone in the United States, 65.4 per cent said yes and 31.4 per cent said they have regular e-mail contact with friends, co-workers or relatives in the United States. One-third (36.5 per cent) had visited the United States and 92.5 per cent said they would like to do so.

\section{Hong Kong}

Seventy-five per cent of the students who participated were female and 25 per cent were male. Average age of the participants was 24 years, with a range of $20-51$. None claimed English was their native language, although 72 per cent said they spoke English fluently and all were studying in an English-language university. Native languages were Chinese (53.8 per cent) or Cantonese (46.2 per cent).

Most participants indicated that they were citizens of China (55.2 per cent), although some listed Hong Kong as their 'country' of citizenship (39.7 per cent). One student was from the United Kingdom. Asked if they knew anyone in the United States, 72.7 per cent said yes and 45.5 per cent said they have regular e-mail contact with friends, co-workers or relatives in the United States. About one-fourth (27.3 per cent) had visited the United States and 94 per cent said they would like to do so.

\section{Singapore}

Seventy per cent of the students who participated were female and 30 per cent were male. Average age of the participants was 23.5 years, with a range of 16-43. Fifty-five per cent claimed English was their native language. The rest indicated several native languages, including Chinese (25.9 per cent), Malay (7.9 per cent) and Tamil (4.6 per cent), respectively. Ninetyfive per cent said they spoke English fluently.

Most participants were from Singapore (87.0 per cent), followed by China (6.0 per cent) and Malaysia (4.1 per cent). In terms of ethnicity, the majority of students were Chinese (70.9 per cent), followed by Indian (11.5 per cent), Malay (10.5 per cent), Indonesian (2.0 per cent) and Eurasian (2.0 per cent). Asked if they knew anyone in the United States, 70.6 per cent said yes and 49.2 per cent said they have regular e-mail contact with friends, co-workers or relatives in the United States. One-third (35.4 per cent) had visited the United States and 95.8 per cent said they would like to.

1. What are the prevailing attitudes towards America by students in Australia, Hong Kong and Singapore? Attitudes towards America were measured on two dimensions: favourability towards the US Government and favourability towards the US people. Students in all countries indicated more favourable attitudes towards the US people than towards the US Government.

Australian students gave a mean favourability rating of 1.91 to the US Government and 2.60 to the US people (on a 4-point scale with 1 being very unfavourable and 4 being very favourable). Students in Hong Kong also rated the US Government 1.91 on average and the US people 2.64. Singaporean students rated the US Government slightly higher at 2.38 and the US people also higher at 2.82 .

2. Which American brands do students in Australia, Hong Kong and Singapore like most? Least? Favourite brands mentioned by students in Australia included Coca-Cola (12.4 per cent) and McDonald's (9.9 per cent). McDonald's was also the most frequently mentioned US brand that the students in Australia said they disliked.

Favourite brands mentioned by students in Hong Kong included Coca-Cola, 
Table 1: Percentage of most-liked US brands in Australia, Hong Kong and Singapore

\begin{tabular}{lccc}
\hline & Australia $(\boldsymbol{n}=\mathbf{1 6 1 )}(\mathbf{\%})$ & Hong Kong $\mathbf{( n = 6 7 )}(\mathbf{\%})$ & Singapore $(\boldsymbol{n}=\mathbf{3 2 8}) \mathbf{( \% )}$ \\
\hline Coca-Cola & 12.4 & 13.4 & 6.1 \\
McDonald's & 9.9 & 11.5 & 4.2 \\
Nike & 9.3 & 13.4 & 14.9 \\
Adidas* & 2.5 & 4.5 & 0.6 \\
Oreo & 2.5 & & 0.3 \\
Bud Light & 1.9 & 4.5 & 0.3 \\
Levi's & 1.9 & 4.5 & 9.1 \\
Microsoft & 1.9 & & 2.7 \\
Ralph Lauren & 1.9 & & 0.3 \\
Subway & 1.9 & 1.5 & 0.3 \\
Gap & & 3.0 & 3.4 \\
Victoria's Secret & & & 3.0 \\
\hline
\end{tabular}

${ }^{*}$ Adidas is a German-owned company

Table 2: Percentage of most-disliked US brands in Australia, Hong Kong and Singapore

\begin{tabular}{llll}
\hline & $\begin{array}{l}\text { Australia } \\
(\boldsymbol{n}=\mathbf{1 6 1 )}(\mathbf{\% )}\end{array}$ & $\begin{array}{l}\text { Hong Kong } \\
(\boldsymbol{n}=\mathbf{6 7 )} \mathbf{( \% )}\end{array}$ & $\begin{array}{l}\text { Singapore } \\
(\boldsymbol{n}=\mathbf{3 2 8}) \mathbf{( \% )}\end{array}$ \\
\hline McDonald's & 15.5 & 7.5 & 2.7 \\
Nike & 11.8 & 3.0 & 1.8 \\
Coca-Cola & 3.7 & & 0.9 \\
Starbucks & 3.7 & & 0.9 \\
Microsoft & 1.9 & 1.5 & 1.2 \\
Tommy Hilfiger & & 3.0 & 1.5 \\
President Bush & & & \\
\hline
\end{tabular}

Table 3: Preference for US brands in Australia, Hong Kong and Singapore

\begin{tabular}{lccc}
\hline & $\begin{array}{l}\text { Australia } \\
(\boldsymbol{n}=161)\end{array}$ & $\begin{array}{l}\text { Hong Kong } \\
(\boldsymbol{n}=67)\end{array}$ & $\begin{array}{l}\text { Singapore } \\
(\boldsymbol{n}=\mathbf{3 2 8})\end{array}$ \\
\hline $\begin{array}{l}\text { I refuse to buy US brands. } \\
\text { Most of the time I will NOT buy products with a US brand if I can find }\end{array}$ & 0.0 & 0.0 & 0.0 \\
$\begin{array}{l}\text { another one not from the US. } \\
\text { I do not care if the products that I buy are from the US or not, I choose the } \\
\text { products that I like best, regardless of the national origin of the brand. }\end{array}$ & $8.5 \%$ & $3.1 \%$ & $2.6 \%$ \\
$\begin{array}{l}\text { Some of the time I will NOT buy products with a US brand if I can find } \\
\text { another one not from the US. }\end{array}$ & $8.2 \%$ & $7.7 \%$ & $79.2 \%$ \\
I prefer to buy products with US brands. & $1.9 \%$ & $15.4 \%$ & $11.7 \%$ \\
\hline
\end{tabular}

Nike (13.4 per cent each) and McDonald's (11.5 per cent). Although students noted McDonald's as a 'liked brand', another 7.5 per cent included it on their least-liked brand list. Coca-Cola and 'President Bush' tied for the second least-liked brand (3.0 per cent each).

Favourite brands mentioned by students in Singapore included Nike (14.9 per cent) and Levi's (9.1 per cent). The least-liked brands were McDonald's (2.7 per cent), Nike (1.8 per cent) and Tommy Hilfiger (1.5 per cent).

A more complete list of most-liked and most-disliked brands of students from the three countries are listed in Tables 1 and 2, respectively.

3. What is the degree of preference for US brands among students in Australia, Hong Kong and Singapore?

Five responses on a preference continuum (see Table 3) were averaged to form a 'US brand preference' score. It should be noted that the majority of students in the three samples said they 'don't care' whether a brand is from the US when they make purchase decisions, and none said they refuse to buy US brands. Using the 5-point scale (with 5 being a preference for 
US brands), a US brand preference mean score of 3.09 was found among students in Australia, with only 2 per cent opting for the most positive response that they 'preferred to buy US brands'. Students in Hong Kong scored US brand preference at 3.35 , with 15 per cent saying they preferred to buy US brands over others. Singaporean students reported a 3.27 mean score, with 11 per cent saying they prefer to buy US brands.

4. Is there a relationship between degree of US brand preference and attitude towards America?

A Pearson Product correlation test on data from the Australian student sample showed no relationship between attitude towards the US Government or US people and preference for US brands. Among the Hong Kong respondents, a statistically significant positive relationship was, however, found between attitude towards the US Government and preference for US brands $(r=0.301 ; p=0.018)$, but not between the US people and US brands. A similar relationship was also found in Singapore between the US Government and US brand preference $(r=0.205 ; p=0.001)$.

\section{DISCUSSION}

This study explored the relationship between attitudes towards the United States and attitudes towards and preference for US brands among college students in Australia, Hong Kong and Singapore. It is not known to what extent the student groups are representative of their respective countries, or possibly of other students on their own campuses; therefore, any generalisations beyond the sample measured as well as any comparisons between students of the different countries should be viewed with caution. Nonetheless, results from the threecountry survey can be viewed as pilot data and may signal trends that could be further explored among larger and more representative groups.

In terms of prevailing attitudes among the student groups, the Singaporean students expressed the most favourable attitudes towards both the US Government and the US people. In all three countries, as has so often been the case in other surveys (Pew, 2002, 2004), attitude towards the US Government was lower than attitude towards the US people.

Coca-Cola, McDonald's and Nike were among the brands most liked and disliked in all three countries, and Levi's factored as a wellliked brand among the Singaporean students. Nike, Coke and McDonald's are among those rare international brands to which Saatchi \& Saatchi has assigned the status of Lovemarks (Roberts, 2004).

Results of this study of student attitudes indicate that the same brand can occupy both lovemark and loathemark status among the same demographic group, though the basis for neither was measured herein. Roberts (2004) identifies the hallmarks of a lovemark brand, which include emotional attachment and intense loyalty, yet it is not known what the underlying factors might be for loathemarks, as identified in this study. Might anti-Americanism be among the reasons that a lovemark may also take on a loathemark status? Do the same aspects of a brand cause it to be both greatly loved and intensely disliked? Further study among college students as well as among other groups of consumers could address this issue.

While it is thought that the ultimate consumer gesture of distaste for a company or brand is not to patronise or buy it, researchers and marketers are not in agreement about whether consumers abroad allow their purchase decisions to be influenced by their attitudes towards the brand's country (Guyon, 2003; Reinhard, 2003; Gross, 2006). The current study does not offer much to support the notion that college students 'vote with their pocketbooks'. A large majority of students said they 'don't care' about whether a brand comes from the United States when in the marketplace, and more than one in ten of the students in the Hong Kong and Singapore studies said they actually preferred US products over others.

A significant positive relationship was found in both Hong Kong and Singapore between attitude towards the US Government and preference for US brands, while no relationship was found between the two variables among the Australian students. The mixed findings of 
this study make it difficult to settle the disagreement about whether anti-Americanism impacts US brands. Presumably the impact could differ among countries.

Identifying the reasons for these differences is beyond the scope of this study, but perhaps the US Government's perceived embodiment of democratic ideals and business enterprise plays a stronger role in the Asian countries than in Australia. This perception could result in a stronger link being made between the US Government and the desirability of US brands. Conversely, Australia traditionally has been more of an outpost of American culture and commerce and perhaps Australians associate the concept of the US Government more strongly with the actions of the current administration. Hence Australian attitudes towards the US Government are less favourable. This is also supported by the finding in this study of strong US brand preference scores in Hong Kong and Singapore, compared to Australia where only 2 per cent preferred to buy US brands.

More research among larger samples in more countries is obviously needed to fully understand the relationship between attitudes towards US brands and 'Brand America'.

\section{References}

Australian Bureau of Statistics (2006): www.abs.gov.au. Australian Federation of Advertising (2006): www.afa.org.au. Avraham, E. and First, A. (2003) “I buy American': The American image as reflected in Israeli advertising', Journal of Communications, Vol. 53, No. 2, pp. 282-298.

Business for Diplomatic Action (2006) Who we are. Retrieved from http://www.businessfordiplomaticaction.org/who/.

Elliott, S. (2003) 'American companies are adjusting almost everything that represents them overseas', The New York Times, 4th April, p. C5.
Gross, D. (2006, Jan. 11) 'Garcon! Un Coca-Cola, S’il vous plait’, Slate.com. Retreived on 26th September, 2006.

Guyon, J. (2003) 'Brand America', Fortune, 27th October, p. 179.

Kermouch, G., Brady, D., Holmes, S., Moon, I., Kripalani, M. and Picard, J. (2003) 'Brands in an age of anti-Americanism', Business Week, 4th August, pp. 69-71.

Kluver, R. and Fu, W. (2004). The Cultural Globalization Index. Retrieved 1st November, 2004, from www.foreignpolicy. com/story/files/story2494.php.

Love, T. (2003) 'Old ideas fail Brand America', Advertising Age, 7th July, p. 12.

Pew Global Attiudes Project (2006, June) 'U.S. image slips but allies share U.S. concerns over Iran, Hamas. Retrieved on 14th May, 2007 from http://pewglobal.org/reports/display. php?ReportID $=252$.

Pew Research Center for the People and the Press (2002, December). What the World Thinks in 2002: How Global Politics View: Their Lives, Their Countries, the World, America, The Pew Research Center, Washington, DC,WA. Retrieved on 22nd March, 2004, from http://people-press.org/ reports/pdf/165.pdf.

Pew Research Center for the People and the Press (2004, March). A Year After Iraq War: Mistrust in America in Europe Ever Higher, Muslim Anger Persists, The Pew Research Center, Washington, DC, WA. Retrieved on 22nd March, 2004, from http://people-press.org/reports/ pdf/206.pdf.

Reinhard, K. (2003) 'Restoring Brand America', Advertising Age, 23 June, pp. 30-31.

Roberts, K. (2004). Lovemarks: The Future Beyond Brands, PowerHouse Books, New York, NY.

Robertson, J. (2006) 'Asia: Anti-Americanism - Love the money, hate the country', Foreign Direct Investment, 1st March, p. 1.

Romero, S. (2004) 'War and abuse do little harm to U.S. brands', New York Times (cover story), 9th May, pp. 1-11.

The Economist (2005) 'Stars and stripes for ever; American multinationals', The Economist, Vol. 377, No. 8457, 17th December, p. 70.

Telhami, S. (2003). A View from the Arab World: A Survey in Five Countries, The Brookings Institution Press, Washington, DC, WA. Retrieved from http://www.brookings.org/fp/saban/ survey20030313.pdf.

Zogby, J. (2003, 11 August) 'Saudis reject Bin Laden and terrorism', Washington Watch newspaper column. Retrieved from http://www.aaiusa.org/wwatch/081103.htm. 